\title{
Relationship between Sterility and Seedlessness in Citrus
}

\author{
Masashi Yamamoto, Ryoji Matsumoto and Yoshio Yamada* \\ Kuchinotsu Branch, Fruit Tree Research Station, Kuchinotsu, Nagasaki 859-25
}

\begin{abstract}
Summary
The relationship of female and male sterility, and self-incompatibility to seed content in citrus were investigated using 22 male sterile and fertile cultivars. The male fertile cultivars were grouped into self-compatible and self-incompatible. Positive correlation $(r=$ $0.927^{* *}, \mathrm{r}^{2}=0.859$ ) existed between the average number of seeds per fruit obtained by hand pollination, which indicated the degree of female fertility, and that yielded by open pollination. This result indicates that the degree of female fertility and sterility can be estimated from seeds derived by open pollination. The difference between the average number of seeds per fruit by hand pollination and that by open pollination was greater in male sterile cultivars and in self-incompatible cultivars than it was in self-compatible cultivars. This indicates that self-incompatibility as well as male sterility is effective on the reduction of seediness. In open pollination, self-compatible cultivars produced very few seedless fruits, whereas male sterile and self-incompatible cultivars produced many seedless fruits.
\end{abstract}

\section{Introduction}

Seedlessness is a desirable characteristic for both fresh and processed citrus market, thus, it is a major breeding objective. Among the breeding methods for developing seedless cultivars (SpiegelRoy, 1988) are the production of triploid hybrid seedlings (Soost and Cameron, 1969) and creating mutants by irradiation (Hearn, 1986).

While cross breeding to develop diploid seedless cutlivars, we found a close relationship in seediness between hybrid progenies and parents; seedless or few seeded parents frequently produced seedless offsprings, whereas seedy or very seedy parents produced very few seedless offsprings (Yamamoto et al., 1992b). Furthermore, the percentage of seedless progenies was higher in male sterile progenies than in male fertile progenies in the same cross combination (Yamamoto et al., 1993). However, not all male sterile progenies were seedless and some male fertile progenies were seedless (Yamamoto et al., 1993). Similar results were reported by Yoshida (1982) and Yoshida and

Received for publication 24 March 1994.

Contribution No. D-123 of the Fruit Tree Research Station.

* Present address: Okitsu Branch, Fruit Tree Research Station, Okitsu, Shimizu, Shizuoka 424-04.
Hanaori (1990) who investigated male sterility and fertility and seediness of progenies using satsuma mandarins, 'Kiyomi' and 'Sweet Spring' as parents. These results suggest that not only male sterility but also female sterility and self-incompatibility play important roles in developing seedless cultivars.

'Mukaku Kishu' is completely seedless under any conditon. Navel orange and satsuma mandarin are considered to be seedless, but occasionally they produce a few seeds when pollinated. On the other hand, with cross pollination a fruit of some pummelos produces more than one hundred seeds. Female fertility and sterility in Citrus vary with the cultivars (Frost, 1948). The close relationship between female fertility and seediness has long been recognized, but there are a few reports which attribute the degree of female fertility to seediness.

'Kiyomi' and 'Egami Buntan' (C. grandis) are normally seedless, as a result of male sterility and self-incompatibility, respectively (Iwamasa and Ohba, 1980; Nishiura et al., 1983). Furthermore, seediness was less in male sterile progenies than in male fertile progenies in the same cross combination (Yamamoto et al., 1993). However, the effect of male sterility and self-incompatibility on the reduction of seediness under open field condi- 
tions where they are surrounded with much pollen from fertile cultivars has never been clarified.

In the present study, relationship between female sterility and seedlessness, and effects of male sterility and self-incompatibility on the reduction of seediness under open pollination were investigated using many cultivars.

\section{Materials and Methods}

Bearing trees of 22 citrus cultivars grafted on trifoliate orange growing in the Kuchinotsu Branch, Fruit Tree Research Station were used. According to pollen yield and viability obtained under field conditions, all cultivars were divided into two groups; male fertile and male sterile. The male fertile cultivars were divided into two groups; self-compatible and self-incompatible according to previous works (Hearn et al., 1969; Ito and Ueno, 1986; Mishima and Inaba, 1971; Miwa, 1951; Mustard et al., 1956; Nishiura and Iwasaki, 1963; Reece and Register, 1961; Soost,
1956; Takahara et al., 1982; Yamada, 1988).

On May 9, 1990, 50 to 100 flowers on one tree of each cultivar were hand-pollinated with 'Hyuganatsu', which is self-incompatible (Miwa, 1951); it was pollinated with 'Kawachi Bankan'. The flowers were not emasculated or enclosed in bags to prevent open pollination. Fruits from hand and 30 to 100 open pollinated fruits were harvested from each cultivar on November 16 and their seed contents counted.

The degree of female fertility was rated on the basis of the average number of seeds per fruit obtained through hand pollination.

\section{Results}

'Hayasi Unshiu', 'Okitsu Wase', 'Kiyomi' and 'Shirayanagi Navel' belonged to the male sterile group because these cultivars produced very few or no pollen. 'T132 Tankan' produced pollen with low viability (26.8\%). Among 18 male fertile cultivars, 10 were self-incompatible (see Materials and

Table 1. Male fertility, pollen viability and self-compatibility of citrus cultivars.

\begin{tabular}{|c|c|c|c|c|}
\hline $\begin{array}{l}\text { Cultivar } \\
\text { (Latin name or cross combination) }\end{array}$ & $\begin{array}{c}\text { Male } \\
\text { fertility }^{2}\end{array}$ & $\begin{array}{c}\text { Pollen } \\
\text { viability }(\%)\end{array}$ & $\begin{array}{l}\text { Self- } \\
\text { compatibility }\end{array}$ & Reference $^{x}$ \\
\hline 1. Encore (C. nobilis $\times$ C. deliciosa $)$ & MF & 91.9 & SC & - \\
\hline 2.Kara $($ C. nobilis $\times$ C. unshiu $)$ & MF & 89.8 & SC & - \\
\hline 3. Murcott (tangor) & MF & 87.2 & $\mathrm{SC}$ & - \\
\hline 4. Trovita (C. sinensis) & MF & 89.7 & SC & - \\
\hline 5.Fukuhara (C. sinensis) & MF & 67.8 & $\mathrm{SC}$ & - \\
\hline 6. Ponkan cy. Nakano No. 3(C. reticulata) & MF & 89.3 & $\mathrm{SC}$ & - \\
\hline 7.Tankan cv. T132 (C. tankan) & MF & 26.8 & $\mathrm{SC}$ & - \\
\hline 8. Natsudaidai cv. Kawano natsudaidai (C. natsudaidai) & MF & 85.8 & $\mathrm{SC}$ & - \\
\hline 9. Clementine (C. clementina) & MF & 84.5 & SI & 1 \\
\hline 10. Minneola (C. paradisi $\times$ C. tangerina) & MF & 89.7 & SI & 2 \\
\hline 11.F airchild $($ C. clementina $\times$ tangelo $)$ & MF & 86.2 & SI & 3 \\
\hline 12. Page (tangelo $\times$ C. clementina) & MF & 82.1 & SI & 4 \\
\hline 13. Robinson (C. clementina $\times$ tangelo $)$ & $\mathrm{MF}$ & 87.0 & SI & 5 \\
\hline 14. Hyuganatsu (C. tamurana) & MF & 95.4 & SI & 6 \\
\hline 15. Hassaku (C. hassaku) & MF & 92.5 & SI & 7 \\
\hline 16. Kawachi Bankan & MF & 92.8 & $\mathrm{SI}$ & 8 \\
\hline 17. Tosa Buntan (C. ootachibana) & MF & 90.9 & SI & 9 \\
\hline 18. Hirado Buntan (C. grandis) & MF & 87.8 & SI & 10 \\
\hline 19. Hayashi Unshiu (C. unshiz) & MS & - & - & - \\
\hline 20.Okitsu Wase (C. unshiu) & MS & - & - & - \\
\hline 21. Kiyomi (C. unshiu $\times$ C. sinensis) & MS & - & - & - \\
\hline 22.Shirayanagi Navel (C. sinensis) & MS & - & - & - \\
\hline
\end{tabular}

$z$ MF: Male fertility, MS: Male sterility.

y SC: Self-compatibility. SI: Self-incompatibility.

x 1: Soost. (1956) , 2: Mustard et al. (1956), 3: Takahara et al. (1982), 4: Hearn et al. (1969), 5: Reece and Register (1961) , 6: Miwa (1951) , 7: Nishiura and Iwasaki (1963) , 8: Mishima and Inaba (1971), 9: Yamada (1988), 10: Ito and Ueno (1986). 
Methods) and 8 were self-compatible. Consequently, of 22 cultivars, 4 were male sterile; 8 selfcompatible group; 10 self-incompatible group (Table 1).

The average number of seeds per fruit by open pollination ranged from 0 to 2.7 in all male sterile cultivars. In 'T132 Tankan' and 2 self-incompatible cultivars; 'Page' and 'Robinson', the seed count ranged from 1.6 to 2.1 ; whereas in 'Kara', 'Trovita', 'Fukuhara', Ponkan and Clementine, the range was from 4.2 to 7.3 . In two cultivars, 'Hirado Buntan' and 'Tosa Buntan', the seed counts were 61.9 and 46.1, respectively (Table 2).

All open pollinated male sterile cultivars produced very high percentage of seedless fruits, ranging from 100 in 'Okitsu Wase'; 91 in 'Shira- yanagi Navel'; 90 in 'Hayashi Unshiu'; and 44 in 'Kiyomi'. Out of 10 open pollinated self-incompatible cultivars, 7 produced seedless fruits; among which 'Page' had 67\%. On the other hand, among the 8 open pollinated self-compatible cultivars only 3 produced seedless fruits, but their range of seedless fruits were from 1 to $25 \%$ (Table 2).

The relationship between the average seed number of open and hand pollinated revealed a posi. tive coefficient of correlation, $r=0.927^{* *}$ (Fig. 1). However, this coefficient of correlation was strongly affected by two very seedy cultivars, 17 : 'Tosa Buntan' and 18: 'Hirado Buntan'. A coefficeint of correlation derived by excluding these cultivars was $\mathrm{r}=0.788^{* *}$

The ratio of the average seed number from open

Table 2. Number of seeds per fruit and percentage of seedless fruits of open pollination, and number of seeds per fruit and percentage of seedless fruits of hand pollination.

\begin{tabular}{|c|c|c|c|c|c|c|c|}
\hline \multirow[b]{2}{*}{ Cultivar } & \multicolumn{3}{|c|}{ Open pollination } & \multicolumn{4}{|c|}{ Hand pollination ${ }^{2}$} \\
\hline & $\begin{array}{l}\text { Number of } \\
\text { fruits } \\
\text { investigated }\end{array}$ & $\begin{array}{l}\text { Number of } \\
\text { seeds per } \\
\text { fruit }\end{array}$ & $\begin{array}{l}\text { Percentage } \\
\text { of seedless } \\
\text { fruits }\end{array}$ & $\begin{array}{l}\text { Number of } \\
\text { flowers } \\
\text { pollinated }\end{array}$ & $\begin{array}{l}\text { Number of } \\
\text { fruits } \\
\text { investigated }\end{array}$ & $\begin{array}{l}\text { Number of } \\
\text { seeds per } \\
\text { fruit }\end{array}$ & $\begin{array}{c}\text { Percentage } \\
\text { of seedless } \\
\text { fruit }\end{array}$ \\
\hline \multicolumn{8}{|l|}{ Self-compatibility } \\
\hline 1.Encore & 100 & $15.4 \pm 0.7$ & 0.0 & 100 & 58 & $23.2 \pm 0.8$ & 0.0 \\
\hline 2. Kara & 100 & $6.8 \pm 0.6$ & 11.0 & 100 & 60 & $12.1 \pm 0.8$ & 0.0 \\
\hline 3. Murcott & 100 & $13.7 \pm 0.5$ & 0.0 & 100 & 69 & $18.4 \pm 0.5$ & 0.0 \\
\hline 4. Trovita & 100 & $7.8 \pm 0.4$ & 0.0 & 100 & 18 & $12.3 \pm 1.4$ & 0.0 \\
\hline 5. Fukuhara & 100 & $6.6 \pm 0.3$ & 0.0 & 100 & 12 & $7.3 \pm 0.9$ & 0.0 \\
\hline 6.Ponkan & 100 & $4.2 \pm 0.2$ & 1.0 & 100 & 16 & $4.8 \pm 0.5$ & 6.7 \\
\hline 7. Tankan & 100 & $1.8 \pm 0.2$ & 25.0 & 100 & 51 & $2.8 \pm 0.3$ & 15.7 \\
\hline 8. Natsudaidai & 50 & $21.8 \pm 0.9$ & 0.0 & 50 & 10 & $26.8 \pm 2.1$ & 0.0 \\
\hline \multicolumn{8}{|l|}{ Self-incompatibility } \\
\hline 9. Clementine & 100 & $7.3 \pm 0.5$ & 4.0 & 100 & 78 & $13.4 \pm 0.5$ & 0.0 \\
\hline 10. Minneola & 100 & $10.8 \pm 1.1$ & 14.0 & 100 & 63 & $35.5 \pm 0.7$ & 0.0 \\
\hline 11. Fairchild & 100 & $12.1 \pm 0.8$ & 0.0 & 100 & 55 & $32.1 \pm 0.9$ & 0.0 \\
\hline 12. Page & 100 & $1.6 \pm 0.3$ & 67.0 & 50 & 23 & $10.4 \pm 1.0$ & 0.0 \\
\hline 13. Robinson & 100 & $2.1 \pm 0.3$ & 45.0 & 60 & 34 & $12.4 \pm 1.1$ & 0.0 \\
\hline 14. Hyuganatsu & 50 & $20.9 \pm 1.4$ & 0.0 & 100 & 27 & $38.8 \pm 1.2$ & 0.0 \\
\hline 15. Hassaku & 100 & $11.3 \pm 1.6$ & 39.0 & 100 & 82 & $49.9 \pm 1.4$ & 0.0 \\
\hline 16. Kawachi Bankan & 100 & $21.0 \pm 1.7$ & 13.0 & 100 & 65 & $58.6 \pm 1.5$ & 0.0 \\
\hline 17. Tosa Buntan & 50 & $46.1 \pm 3.3$ & 0.0 & 50 & 30 & $89.9 \pm 4.4$ & 0.0 \\
\hline 18. Hirado Buntan & 30 & $61.9 \pm 6.8$ & 10.0 & 100 & 24 & $97.8 \pm 5.4$ & 0.0 \\
\hline \multicolumn{8}{|l|}{ Male-sterility } \\
\hline 19. Hayashi Unshiu & 100 & $0.2 \pm 0.1$ & 90.0 & 100 & 77 & $3.1 \pm 0.2$ & 13.0 \\
\hline 20. Okitsu Wase & 100 & $0.0 \pm 0.0$ & 100.0 & 100 & 53 & $0.03 \pm 0.0$ & 96.2 \\
\hline 21. Kiyomi & 50 & $2.7 \pm 0.6$ & 44.0 & 100 & 37 & $19.8 \pm 1.8$ & 2.7 \\
\hline 22. Shirayanagi Navel & 100 & $0.2 \pm 0.1$ & 91.0 & 100 & 11 & $2.8 \pm 0.3$ & 0.0 \\
\hline
\end{tabular}

2 Flowers of all cultivars except Hyuganatsu were hand pollinated with Hyuganatsu pollen. Hyuganatsu flowers were hand pollinated with Kawachi bankan pollen.

$y$ Number of fruits set. 


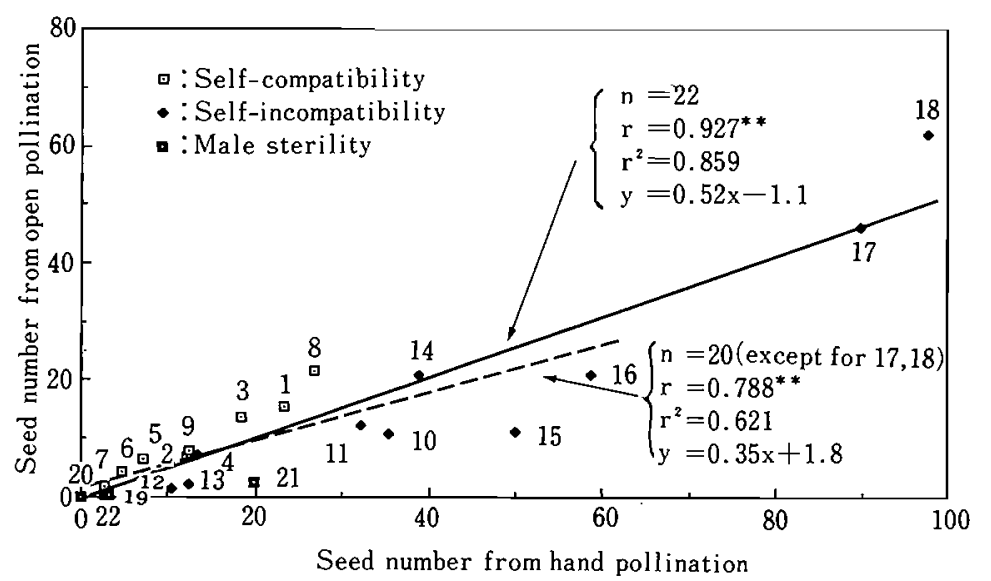

Fig. 1. Relationship between seed number of hand pollination and open pollination. Cultivar No. (1-22): same as Table 1 . Solid line is obtained including crs. No. 17 and 18 , while broken line is obtained excluding cvs. No. 17 and 18 .

pollination to that of hand pollination (OP/HP), expressed as a percentage in the self-compatible group, 1,4 and 3 cultivars revealed ranges from $40.0 \sim 59.9 \%, 60.0 \sim 79.9 \%$ and $80.0-99.9 \%$, respectively (Fig. 2). In the self-incompatible group, $2,4,3$ and 1 cultivars, the ratio ranges from 0.0 $\sim 19.9 \%, 20.0 \sim 39.9 \%, 40.0 \sim 59.9 \%$ to $60.0 \sim$ $79.9 \%$, respectively. In the 4 male sterile cultivars, the ratio ranged from 0.0 to $19.9 \%$. The $\mathrm{OP} / \mathrm{HP}$ ratio was the lowest in the male sterile

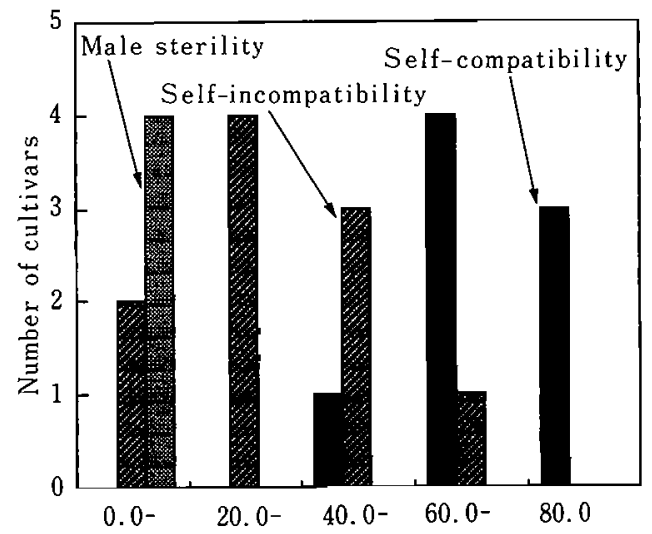

Percentage of seed number of open pollination to that of hand pollination

Fig. 2. Distribution of percentage of seed number of open pollination to that of hand pollination. group; it was lower in the self-incompatible group than in the self-compatible group.

In male sterile and self-incompatible groups, a negative correlation existed between the percentage of seedless fruits derived from open pollination and the OP/HP percentage (Fig. 3).

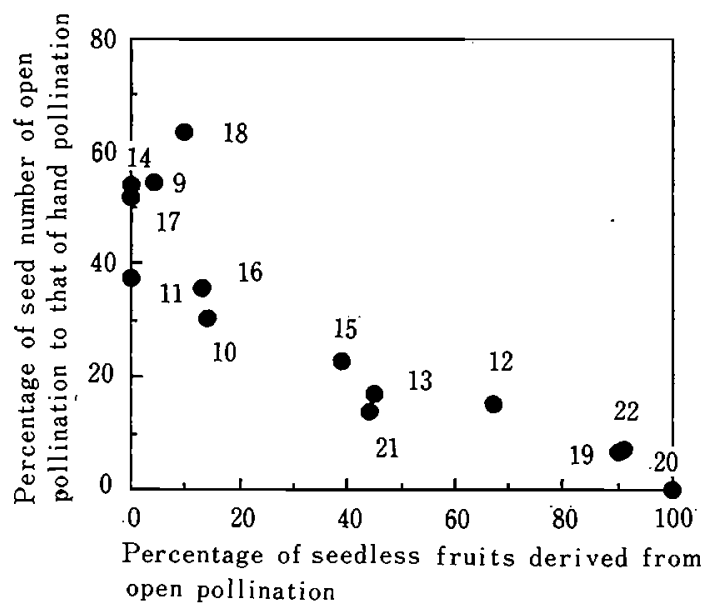

Fig. 3. Relationship between percentage of seedless fruits of open pollination and percentage of seed number of open pollination to that of hand pollinations in self-incompatible and male sterile cultivars. Cultivar No. (9-22): same as Table 1. 


\section{Discussion}

The role of male sterility which is very actively investigated in citrus, has resulted in seedless Japanese cultivars (Matsumoto et al., 1991; Nishiura et al., 1983). Results of cross pollination studies revealed the degree of female fertility and sterility vary greatly among cultivars (Nagai and Tanikawa, 1926; Nishiura and Iwasaki, 1963). The mechanism of self-incompatibility is also investigated by. Yamashita and Iwanaga (1984). The close relationship between these sterility and seedlessness has been recognized, but there are few studies which deal with the relationship using many cultivars. By using 22 cultivars in this study, it becomes apparent that female sterility, male sterility and self-incompatibility influence seedlessness in fruits derived from open pollinated flowers.

Since seed formation in citrus fruits is affected by both genetic and environmental factors, seediness varies even in the same cultivar depending on time and planting area. The environmental effects on seediness was not clarified in this study because our data were obatined only in one year and at one place. It is clear, however, that among genetic factors influencing seediness, female fertility is directly related to seediness. Positive correlation $\left(\mathrm{r}=0.927^{* *}, \mathrm{r}=0.788^{* *}\right)$ was found between seed number of hand pollination and that of open pollination. This indicates that the degree of female fertility can be estimated from the seed number of open pollination. Previously (Yamamoto et al., 1993), positive correlation $\left(r=0.722^{* *}\right)$ was found between the average number of seeds per fruit in hybrids and their parents. Results from this study and previous reports show that female fertility and sterility are heritable characteristics. Thus, we must pay attention to female sterility in the breeding of seedless cultivars.

In all cultivars, average number of seeds per fruit was greater by hand pollination than by open pollination. In addition, the percentage of OP/HP was smaller in self-incompatible cultivars and male sterile cultivars than it was in self-compatible cultivars. The lower seed number in open pollination than in hand pollination indicates that a low order of pollination occurs under open field conditions compared with hand pollination. The male sterile and self-incompatible cultivars have a smaller chance of fertilization than have the selfcompatible cultivars because the former needs compatible pollen to produce seeds. Thus, a greater difference was observed between seed number of hand pollination and open pollination in male sterile and self-incompatible cultivars. Consequently, male sterility and self-incompatibility reduce seediness and increase the percentage of seedless fruits. However, in some self-incompatible cultivars, the percentage of $\mathrm{OP} / \mathrm{HP}$ is as high as ithat of self-compatible cultivars. It is supposed that in those self-incompatible cultivars, the number of seedless fruits probably decreased because they do not set parthenocarpically and set only seedy fruits. In most cases, the difference between seed count from hand pollination and open pollination was generally greater as the percentage of seedless fruits by the open pollination was higher in male sterile and self-incompatible cultivars. Certainly, parthenocarpy is indispensable because any cultivar which is both male and female sterile would be incapable of producing seedless fruit.

Seedless cultivars such as 'Hayashi Unshiu', 'Okitsu Wase' and 'Shirayanagi Navel' are both fenıale and male sterile. 'T132 Tankan' is female sterile to a similar degree as the above cultivars, but it is self-compatible in spite of low pollen viability. Thus, open pollinated fruits of 'T132 Tankan' is seedier than those of 'Hayashi Unshiu', 'Okitsu Wase' and 'Shirayanagi Navel'. 'Kiyomi', which is considered to be a seedless cultivar, is completely male sterile (Nishiura et al., 1983). However, seediness of 'Kiyomi' often increases when cross pollinated by male fertile cultivars because its degree of female fertility is high. Consequently, female sterility coupled with male sterility or self-incompatibility is essential to the development of seedless cultivars.

The results obtained in this study indicate a close relationship between sterility and seedlessness. Further investigations to elucidate inheritance patterns of sterility are needed to develop seedless cultivars efficiently. Several studies on inheritance of male sterility have been made (Iwamasa, 1966; Ueno, 1986; Vardi and Spiegel-Roy, 1981; Yamamoto et al., 1992a), and the results of which have been applied in selection of parents. Although there is a close relationship between female sterility and seedlessness, comparatively little is known about the inheritance of female 
sterility (Nesumi et al., 1992). The inheritance pattern of self-incompatibility has already been reported, e.g., some self-compatible cultivars such as grapefruit and 'Dancy' tangerine carry a selfincompatible gene (Soost, 1965). However, the distribution of the self-incompatible gene is not well known. Parthenocarpy is necessary for developing seedless cultivars; very little information regard. ing its inheritance pattern is available (Ueno, 1976). Hence, further investigation must be conducted to elucidate the inheritance of the sterility system and the parthenocarpy.

\section{Acknowledgments}

We thank trainees of Kuchinotsu branch, Fruit Tree Research Station for their assistance and also thank to Dr. S. Iwahori, Professor of the Institute of Agriculture and Forestry, University of Tsuku$\mathrm{ba}$, for reading the manuscript.

\section{Literature Cited}

Frost, H. B. 1948. Seed production: development of gametes and embryos. In: H. J. Webber and L. D. Batchelor (eds.). The Citrus industry. Vol. 1. 767-815. Univ. Calif. Press, Berkeley and Los Angeles.

Hearn, C. J. 1986. Development of seedless grapefruit cultivars through budwood irradiation. J. Amer. Soc. Hort. Sci. 111: 304-306.

Hearn, C. J., P. C. Reece and R. Fenton. 1969. Selfincompatibility and the effect of different pollen sources upon fruit characteristics of four Citrus hybrids. Proc. First Int. Citrus Symp. 1 : 183-187.

Ito, Y. and I. Ueno. 1986. Studies on the incompatibility in citrus. Annual Rep. Okitsu Branch, Fruit Tree Res. Stn. 1986. 12. (In Japanese).

Iwamasa, M. 1966. Studies on the sterility in genus Citnus with special reference to the seedlessness. Bull. Hort. Res. Sta. B6 : 1-82.

Iwamasa, M. and Y. Ohba. 1980. Seedlessness due to self-incompatibility in Egami-Buntan, a Japanese pummelo cultivar. Bull. Fac. Agr., Saga Univ. 49 ; 39-45. (In Japanese with English summary).

Matsumoto, R., N. Okudai, I. Oiyama, T. Takahara, M. Yamamoto, K. Asada, D. Ishiuchi and H. Murata. 1991. New citrus cultivar 'Tsunokaori'. Bull. Fruit Tree Res. Stn. $21: 59-65$. (In Japanese with English summary).

Mishima, K. and I. Inaba. 1971. Studies on the ecological adaptation of Kawachi-Bankan. [1] Influence of the cross pollination on the form, seeded and dropping. Kyushu Agr. Research $33: 273-274$.
(In Japanese).

Miwa, T. 1951. Pollination, fertilization, and fruit drop in Citrus tamurana Hort. Bull. Miyazaki Univ. (Natural Science) $2: 1-67$. (In Japanese with English summary).

Mustard, M. J., S. Y. Lynch and O. Nelson. 1956. Pollination and floral studies of the Minneola tangelo. Proc. Fla. State Hort. Soc. 69 : 277-281.

Nagai, K. and T. Tanikawa. 1926. On citrus pollination. Proc. Third Pan-Pacific Soc. Congress 2023-2029.

Nesumi, H., Y. Ito, T. Yoshioka and T. Yoshida. 1992. Female sterility of 'Mukakukishu' and its inheritance. J. Japan. Soc. Hort. Sci. 61 (Suppl. 1): 36-37. (In Japanese).

Nishiura, M. and T. Iwasaki. 1963. Studies on the citrus breeding. I. Variation of seed formation in citrus crossing. Bull. Hort. Res. Sta. B2 : 1-13. (In Japanese with English summary).

Nishiura, M., T. Shichijo, I. Ueno, M. Iwamasa, T. Kihara, Y. Yamada, T. Yoshida and T. Iwasaki. 1983. New citrus cultivar 'Kiyomi' tangor. Bull. Fruit Tree Res. Stn. B10 : 1-9. (In Japanese with English summary).

Reece, P. C. and R. O. Register. 1961. Influence of pollinators on fruit set on Robinson and Osceola tangerine hybrids. Proc. Fla. State Hort. Soc. 74 : 104-106.

Soost, R. K. 1956. Unfruitfulness in the Clementine mandarin. Proc. Amer. Soc. Hort. Sci. 67 : 171-175.

Soost, R. K. 1965. Incompatibility alleles in genus Citrus. Proc. Amer. Soc. Hort. Sci. 87 : 176-180.

Soost, R. K. and J. W. Cameron. 1969. Tree and fruit characters of Citms triploid from tetraploid by diploid cross. Hilgardia 39 : 569-579.

Spiegel-Roy, P. 1988. Citrus breeding - past, present and future. Proc. Sixth Int. Citrus Congress 1 : 9-17.

Takahara, T., I. Oiyama and N. Okudai. 1982. Effect of tetraploid as the production of seedless fruits in self-incompatible cultivars in citrus. Bull. Fruit Tree Res. Stn. D4 : 11-24. (In Japanese with English summary).

Ueno, I. 1976. Parthenocarpy of tangor and tangelo using satsuma mandarin as seed parent. Abstr. Japan. Soc. Hort. Sci. Spring Meet. 1976. 94-95. (In Japanese).

Ueno, I. 1986. Studies on the inheritance of citrus flower characteristics. I. Segregation of viable pollen production in hybrid seedlings. Bull. Fruit Tree Res. Stn. B13 : 1-9. (In Japanese with English summary).

Vardi, A. and P. Spiegel-Roy. 1981. Gene controlled meiosis in Citrus reticulata. Proc. Int. Soc. Citriculture 26-27. 
Yamada, Y. 1988. Characteristics of mid and late maturing citrus and their cultivation. Abstr. Symp. Japan. Soc. Hort. Sci. Autumn Meet. 1988. 1-19. (In Japanese).

Yamamoto, M., N. Okudai and R. Matsumoto. 1992a. Studies on the inheritance of aborted anthers in citrus using seed parents having aborted anthers. J. Japan. Soc. Hort. Sci. 60 : 791-797. (In Japanese with English summary).

Yamamoto, M., Y. Yamada, R. Matsumoto, H. Ikemiya and N. Okudai. 1992b. Inheritance of seed number in citrus. Bull. Fruit Tree Res. Stn. 23 : 47-56. (In Japanese with English summary).

Yamamoto, M., N. Okudai, R. Matsumoto and Y. Yamada. 1993. Seed number of hybrid plants in citrus, with special reference to seed number of parents and pollen yield of individuals. J. Japan. Soc. Hort.
Sci. 61 : 757-762. (In Japanese with English summary).

Yamashita, K. and H. Iwanaga. 1984. Physiological characteristics of immature flower buds as concerned with self-incompatibility of Hyuganatsu, Citrus tamurana Hort. ex Tanaka. J. Japan. Soc. Hort. Sci. 53 : 6-12. (In Japanese with English summary).

Yoshida, T. 1982. Pollen viability and seed content in hybrid seedlings using 'Sweet Spring' or 'Kiyomi' as seed parents. Abstr. Japan. Soc. Hort. Sci. Spring Meet. 1982. 10-11. (In Japanese).

Yoshida, T. and H. Hanaori. 1990. Pollen viability and seed content in satsuma mandarin hybrids. J. Japan. Soc. Hort. Sci. 59 (Suppl. 1): 8-9. (In Japanese).

\title{
カンキツにおける不稔性と含核数との関係
}

\author{
山本雅史・松本亮司・山田涁雄
}

果樹試験場口之津支場 859-25 長崎県南高来郡口之津町

\begin{abstract}
摘要
カンキツに扔ける雌性不稔性，雄性不棇性および自 家不和合性と含核数との関係をカンキッ 22 品種を用 いて調査した。

1. 自然受粉区と人工受粉区の含核数との間には正 の相関 $\left(r=0.927^{* *}, r^{2}=0.859\right)$ が認められた. 人 工受粉区の含核数は羟性不稔性の程度を表わしている と考えられることから，雌性不䅮性は自然受粉果の含 核数に強い影留を及ほしていることが推察できた。

2. 人工受粉果の含核数に対する自然受粉果の含核

び自家不和合性品種で低く，雄性不稳性および自家不 和合性は，含核数を減少させる効果があることが確認 できた。

3. 一部の自家不和合性品種の人工受粉果に対する 自然受粉果の含核数の割合は, 自家和合性品種と同程 度であった。これらの品種においては無核果がほとん ど結実していなかった。これは，単為結果性の欠如の ため，有核果のみが結実したので，このような結果に なったものと考えられた。
\end{abstract} 数の割合は, 自家和合性品種より雄性不稔性品種およ 